\title{
Teaching Vocabulary Using Semantic Mapping Technique
}

\author{
Arief Styo Nugroho ${ }^{1}$, Ira Arini ${ }^{2}$ \\ ${ }_{1,2}^{1,}$ STKIP Setiabudhi \\ Email: ariefstyo@gmail.com
}

\begin{abstract}
The aim of this research is to find out the effectiveness of Semantic Mapping technique in teaching vocabulary. Therefore, the hypothesis in this research is the student who are taught by Semantic Mapping technique achieve better than before. The design used in this research is the Pre-Experiment Design. It also has several forms such as a One-Shot Case Research, One-Group Pretest-Posttest Design, One-Group Pretest and Posttest Design also Intact-Group Comparison. One-group pretest and posttest for this research, it means there will be a pretest before giving treatment to the sample and posttest after ending the treatment. In collecting data, Pre-test and Post-test are employed. The tests are multiple choices and complete the sentences. It consists of twenty questions. The right answer will be get 1 point and for the wrong answer is zero (0). The result of this research in pretest that the highest score was 16, the lower score was 9, the median was 13,00, the mode was 14 mean was 12,90, standard deviation was 1,863, range was 7 and total score of pretest is 387. The posttest was the highest score was 20, the lower score was 14, the median was 17,00, the mode was 16 mean was 17,07, standard deviation was 1,388, range was 6 and total score of post-test is 512. The conclusion is drawn by analyzing the average scores of pretest and posttest by using t-test formula; Sig value is $0,000<0,05$ it means that alternative hypothesis $(H A)$ is accepted.

Keywords: Semantic, Mapping, Technique
\end{abstract}

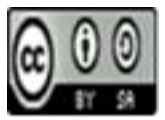




\section{Introduction}

To learn a language, students are required to master language components, one of them is vocabulary. Vocabulary mastery in language learning facilitates students to understand, vocabulary itself is a core component of language proficiency and becomes the basis for how well the learners listen, speak, read, and write. Without having vocabulary mastery, it is difficult for learners to convey the information which they want to express. Meanwhile, with a good knowledge of vocabulary, learners may feel confident in communication either spoken or written.

To have a good vocabulary acquisition is not easy for the first young learner that is the students of pre-intermediate and intermediate level. The reason is the student level of thinking is different and vocabulary mastery itself is very difficult, it can be seen from the student score average not far from the minimum score. Some students can memorize many words but others cannot, while for learning vocabulary it is needed many words, strong, memorization and also practicing.

Based on researcher's experience during teaching learning practice, there are several problems related to teaching of vocabulary. First, students get difficulties in learning English since their English vocabularies are limited, finally students often get bad score especially in terms speaking and writing. Second, students get difficulties to memorize new English words, it caused by lack motivation to increase students' vocabulary mastery. The third is the methods used by the teacher do not encourage students to use their vocabulary. The teacher only asked student to open dictionary and try to find the meaning on the dictionary. Such activities demotivate students to learn. Thus, it create bored teaching learning process atmosphere.

Related to the problem above, appropriate and different technique from the conventional method is needed. It's done to create enjoyable atmosphere, encourage students to get involved in teaching learning process, stimulate them to use the words which is they have already known and brainstorm the new words related to the topic. Therefore, Semantic Mapping is chosen to be employed to solve such problems.

The Semantic Mapping strategy, sometimes called as a schematic diagram of the major concepts in a portion of text. The researcher uses the Semantic Mapping strategy because this strategy can easily be taught and implemented by the students, in addition to its significant role in developing students' thinking skills and vocabulary comprehension. Semantic Mapping can also helping students brainstorm and generate new ideas, encouraging students to discover new concepts and the propositions that connect them and allow tudents to more clearly communicate ideas, thoughts and information.

Referring to the students' vocabulary problem and benefits of Semantic Mapping, this research is conducted. It entitles "Teaching Vocabulary Using Semantic Mapping". Based on the formulation of problem above, the aim of this research is to find out the effectiveness of Semantic Mapping technique in teaching vocabulary.

As already described, the use of the Semantic Mapping resulted in significant improvement in the reading comprehension achievement of the EG students. By comparing the average scores from the pre-test and the post-test of the EG, it was found that the percentage improvement in reading comprehension for those students was about 28\% (Kasim \& Wahyuni, 2015). In other research, the implementation of semantic mapping has improved the students' writing skill. It was proved that improvement score from the pre-test and post-test (Siddiq, 2012).

Vocabulary is central to language and is great significance to language learners (Marianne, 1991), it means that vocabulary very important in language. The students with enough vocabulary will be able to use language correctly and easier to understand English lessons such speaking, listening, and writing. By having low ability in vocabulary, it is difficult for learners to convey the information which they want to express. Meanwhile, with a good knowledge of vocabulary, learners may feel confident in communication either spoken or written.

Semantic Mapping strategy allows the students to explore their knowledge of vocabulary by creating a map of word. It consists of a diagram which displays a single word or phrase, placed

Jurnal Sikola: Jurnal Kajian Pendidikan dan Pembelajaran Vol. 3, No. 2, Th. 2021 
in the center as topic and other associated words are added in the form of branches (Indiarti, 2014). According to Graves (Graves, 2008) semantic mapping is one of the most powerful approaches to teach vocabulary because it engages students in thinking about word relationships. Masters, Mori, \& Mori (1993) said the Semantic Mapping used to motivate and involve students in the thinking, reading, and writing aspects. It enhances vocabulary development by helping students' link new information with previous experience.

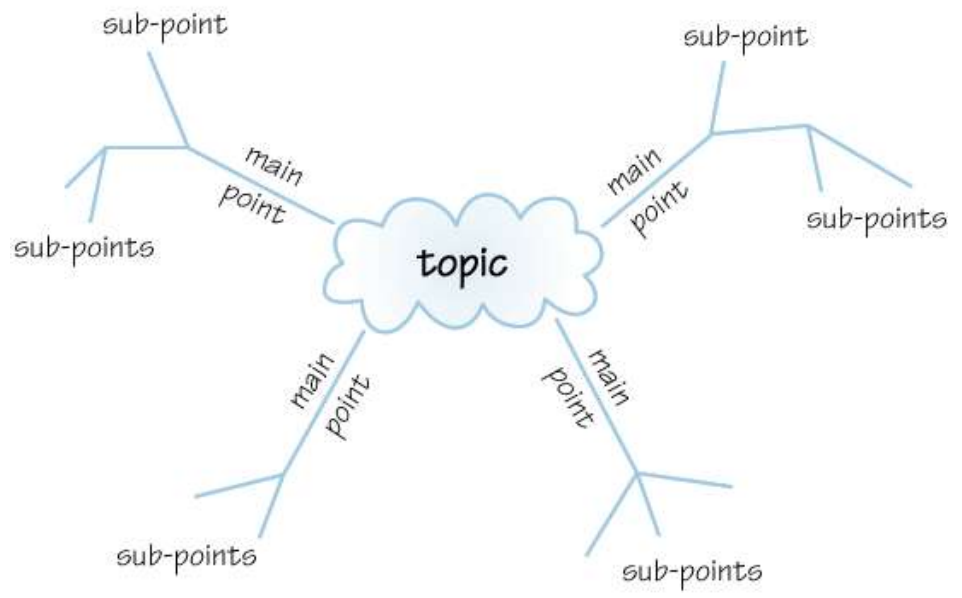

Picture 1. The semantic map

\section{Method}

The design used in this research is the Pre-Experiment Design. It also has several forms such as a One-Shot Case Research, One-Group Pretest-Posttest Design, One-Group Pretest and Posttest Design also Intact-Group Comparison (Sugiyono, 2017) and researcher choose Onegroup pretest and posttest for this research, it means there will be a pretest before giving treatment to the sample and posttest after ending the treatment. This design can be described as follows:

\section{$\mathrm{O}_{1} \mathrm{XO}_{2}$}

Explanation:

$\mathrm{O}_{1}$

$$
\begin{array}{ll}
\mathrm{X} & : \text { Treatment } \\
\mathrm{O}_{2} & \text { : Posttest Value (after treatment) }
\end{array}
$$

In collecting data, Pre-test and Post-test are employed. The tests are multiple choices and complete the sentences. It consists of twenty questions. The right answer will be get 1 point and for the wrong answer is zero (0).

\section{Result and Discussion}

This study was consisted of six meetings. The first meeting was for pre-test, the second to he fifth meetings were treatment and the sixth meeting was post-test. The obtained data were divided into the result of pre-test and post-test. Pre-test was conducted to find out the students' vocabulary mastery before treatment. In collecting data, Pre-test and Post-test are employed. Pretest is conducted to find out the students' vocabulary mastery ability before treatment. While post-test is use to find out the students' reading comprehension ability after treatment. The tests are multiple choices and complete the sentences. It consists of twenty questions. The right answer will be get 1 point and for the wrong answer is zero (0). 
Table 1. Pre-test Score

\begin{tabular}{lc}
\hline & Value \\
\hline $\mathrm{N}$ & 30 \\
Mean & 12,90 \\
Median & 13,00 \\
Mode & 14 \\
Std. Deviation & 1,863 \\
Minimum & 9 \\
Maximum & 16 \\
Sum & 387 \\
\hline
\end{tabular}

The table showed that the highest score was 16 , the lower score was 9 , the median was 13,00 , the mode was 14 mean was 12,90 , standard deviation was 1,863 , range was 7 and total score of pre-test is 387 .

There are one student who got the lower score is 9 , two students got the score 10, six students got score 11, three students got score 12, for students got score 13, seven students got score 14, six students got score 6 and one student got score 16 .

Post-test was conducted to find out the students' vocabulary mastery before treatment. The result could be seen in table 4.2 and graphic 4.2

Table 2. Post-test Score

\begin{tabular}{lc}
\hline & Value \\
\hline $\mathrm{N}$ & 30 \\
Mean & 17,07 \\
Median & 17,00 \\
Mode & 16 \\
Std. Deviation & 1,388 \\
Minimum & 14 \\
Maximum & 20 \\
Sum & 512 \\
\hline
\end{tabular}

The table showed that the highest score was 20 , the lower score was 14 , the median was 17,00 , the mode was 16 mean was 17,07 , standard deviation was 1,388 , range was 6 and total score of post-test is 512 . There are one student who got the lower score is 14 , two students got the score 15 , eight students got score 16, eight students got score 17, six students got score 18, two students got score 19 and one student got score 20.

Before doing the hypothesis test the data should be distributed normality and homogeneity Kolmogorov - Smirnov was utilized to find out normality data. The result could be seen in table 4.3

Table 3. Table Kolmogorov - Smirnov Test

\begin{tabular}{lc}
\hline & Value \\
\hline Mean & 12,9 \\
Std. Deviation & 1,17 \\
Kolmogorov Smirnov Z & 0,835 \\
Sig (2 Tailed) & 0,488 \\
\hline
\end{tabular}

The table showed that the sig value (z) was 0488; it means that data is distributed normally. 
Based on the observation, researcher found that the student was got hesitation because they couldn't remember the word easily and couldn't deliver these words fluently. Moreover, the student feel bored because teacher did not implement a variation technique or another teaching aid, which may attract the students' attention and motivation. After that the teacher asked the student to do the exercise on students' workbook, difficulties because not all of the word in this exercise had given by the teacher so the teacher was in a rush to answer each of students' vocabulary questions, and it was wasting time.

In the present study, Semantic Mapping strategy was applied as a treatment to improve students` vocabulary mastery. The treatment form of this study was teaching-learning process using Semantic Mapping strategy in the classroom. The process of giving treatment to make sure that the Semantic Mapping strategy definitely gave effect to improve students' vocabulary achievement and to know whether Semantic Mapping strategy was more effective to teach vocabulary compared to wordlists strategy as conventional one.

First meeting researcher gave a pre-test with fifteen multiple choice and five complete sentences. Based on the result of pretest, the mean scores is 12,90, median 13,00. From the pretest, it could be said that the basic vocabulary ability of the students was relatively the same before getting the treatment.

After pre-test was given, the treatment of teaching vocabulary by Semantic Mapping strategy was given to the students. The treatment was conducted for 4 meetings. Each meeting needed 90 minutes and had different materials about vocabularies. There were four themes of vocabularies related to procedure text that the teacher gave to the students. Those were vocabulary descriptive text about I Like Elephant, describing animals, my favorite clothes, describing clothes. The process of giving treatment in teaching vocabulary through Semantic Mapping strategy as follows:

\section{First Treatment}

In the first treatment, the students learnt new vocabulary about Elephant through Semantic Mapping strategy. In the beginning of lesson, the researcher gives descriptive text by title "I like Elephant" to stimulate the students 'vocabularies knowledge. Then, researcher wrote a phrase of Elephant as a main topic on the center of board. Next, researcher invited the students to generate as many words as possible related to the topic. The students did brainstorming and classified the words into their categories. Next, they constructed a map of words and also elaborated on their map with the meanings those vocabularies. Individual assignment was given in the end of the lesson related to Semantic mapping, and should memorizing minimal 15 words based on the topic.

\section{Second Treatment}

In the second treatment, the students learnt new vocabulary about "Animals" through Semantic Mapping strategy. Researcher asked students in library to find out and classify words related to animals. Next, students made Semantic Mapping diagram with the meanings those vocabularies based on categories of animal and should memorize minimal 15 words based on the topic.

\section{Third Treatment}

In the third treatment, the researcher gives descriptive text by title "my favorite clothes" then, researcher invited the students one by one to make Semantic Mapping diagram on the board and generate as many words as possible related to the topic. Next, they constructed a map of words and also elaborated on their map with the meanings those vocabularies. Individual assignment was given in the end of the lesson related to Semantic Mapping, and should memorizing minimal 15 words based on the topic. 


\section{Fourth Treatment}

In the fourth treatment, the students learnt new vocabulary about "Clothes" through Semantic Mapping strategy. Researcher showed the students some picture related clothes. Researcher asked the students to make a group and gave them assignment related to Semantic Mapping. Next, the students presented the results of group discussion in front of the class.

In the last activity of the experiment, the researcher gave post-test. In addition, the post test was used to measure the students' vocabulary achievement after getting the treatment. The students were asked to answer 20 questions as similar form as the pre-test but the sentences of question were replaced. The time allocation was also 35 minutes.

\section{Conclusion}

Since the objective of this research is to find out the effectiveness of Semantic Mapping technique in teaching vocabulary, the researcher concludes that the student who are taught by Semantic Mapping technique achieve better than before. The conclusion is drawn by analyzing the average scores of pretest and posttest by using t-test formula; Sig value is $0,000<0,05$ it means that alternative hypothesis (HA) is accepted.

Related to finding and conclusions, some suggestions are offered. Firstly, for English teachers, it is highly recommended for the teachers to use Semantic Mapping as an alternative strategy in teaching vocabulary because of its effectiveness to help the students to improve their vocabulary mastery. It simulate the students to develop their vocabulary through a deeper understanding conceptual knowledge. Therefore, the teachers are expected to use Semantic Mapping strategy because it is effective to improve students' vocabulary mastery and it is promising to vocabulary teaching and learning process. Secondly, for the students, they are suggested to apply Semantic Mapping strategy in organizing and memorizing vocabulary.

\section{Reference}

Graves, M. (2008). Instruction on individual words: One size does not fit all. In A. E. Farstrup\& S. J. Samuels (Eds.), what research has to say about vocabulary instruction (pp. 56-79). Newark, DE: International Reading Association.

Indiarti, I. (2014). The Effectiveness of Semantic Mapping Strategy to Improve Students 'Vocabulary Mastery. Semarang: English Department, Faculty of Languages and Arts, State University of Semarang, Indonesia.

Kasim, U., \& Wahyuni, S. (2015). The Implementation of Semantic Mapping Strategy for Teaching Reading Comprehension. UIN Ar-Raniry.

Marianne, C.-M. (1991). TeachingEnglish as a Second Languageor Foreign Language, 2nd ed. Massachusetts: Heinle \& Heinle Publishers.

Siddiq, A. (2012). The Use of Semantic Mapping to Improve Students' Vocabulary Mastery (A Classroom Action Research at the Seventh Grade Students. UIN Ar-Raniry.

Sugiyono, S. (2017). Metode Penelitian Kuantitatif, Kualitatif, dan R\&D. Bandung: Alfabeta. 